\title{
The balance of organic matter and soil nutrients, depending on fertilization level of soybean varieties
}

\author{
Ekaterina Kotlyarova*, Vitaliy Gritsina, Sergey Litsukov, and Alexey Stupakov \\ Belgorod State Agricultural University named after V. Gorin, 308503 Belgorod, Russian Federation
}

\begin{abstract}
The purpose of the research is to study the effect and interaction of straw-litter compost (20 t/ha), ammonium nitrate $(30 \mathrm{~kg} / \mathrm{ha} \mathrm{N})$ and microfertilizer Azosol 36 Extra (2 times 2 1/ha) on the fertility indicators of typical chernozem for soybean cultivation in the southern forest-steppe of the Central Chernozem region. It was found that the increase in fertilization level based on the use of compost contributed to the positive dynamics of organic matter and macronutrients, the formation of higher yields, protein content and collection. The largest increase in organic matter in the soil was in the variants of joint use of compost and ammonium nitrate $-0.52-0.68 \%$. The combination of compost and ammonium nitrate, as well as the complex application of mineral fertilizers, maintained a positive balance of easily hydrolyzed nitrogen in the soil from 3.3 to $8.2 \mathrm{mg} / \mathrm{kg}$. Perhaps, the earlyripening soybean variety Lantsetnaya mainly used nitrogen of mineral fertilizers for crop formation, while the mid-ripening variety Belgorodskaya 48 is more responsive to the use of compost. The introduction of compost also caused an increase in mobile phosphorus content in the soil by 36-47 $\mathrm{mg} / \mathrm{kg}$ and the exchangeable potassium by $5.4-43 \mathrm{mg} / \mathrm{kg}$. This contributed to the transfer by grouping to a higher gradation - to a high class of supply in terms of the content of both mobile phosphorus $(163-196 \mathrm{mg} / \mathrm{kg})$ and exchangeable potassium $(125-168 \mathrm{mg} / \mathrm{kg})$.
\end{abstract}

\section{Introduction}

The rapid growth of soybean production in the world and in the country is due to the fact that the crop is a source of protein, much cheaper than animal protein; great demand in the countries of its historical consumption; high profitability and demand by numerous industries [1-3].

The production potential of soybeans is significant $-4-5 \mathrm{t} / \mathrm{ha}$ of seeds and more $[4,5]$. To achieve it, a large number of nutrients are required. Despite the high nitrogen supply of soybeans due to nitrogen-fixation - up to $50-70 \%$ of the demand $[6,7]$, this is not enough to realize the bio-production potential.

Over the past decade, the area of soybean crops in the Belgorod region has increased 5 times, reaching 267 thousand hectares [8]. As a result, the share of good precursors and the

* Corresponding author: kotlyarovaeg@mail.ru 
accumulation of biological nitrogen in the soil increased in the structure of sown areas - up to $40 \mathrm{~kg} / \mathrm{ha}$, which is part of the "Biologization of agriculture" program aimed at increase of soil fertility and, ultimately, crop productivity and agricultural sector efficiency $[9,10]$.

The results of studies on the effect of organic, mineral, and trace element fertilizers on the symbiotic activity and efficiency of biological nitrogen use are quite contradictory. Some authors believe that fertilizers, especially nitrogen ones, inhibit the activity of nitrogen-fixing bacteria $[6,7]$, while others, on the contrary, give arguments to confirm their positive effect $[1,11]$.

Thanks to organic matter, the processes of accumulation and mobilization of nutrients and their correlation with plants and soil biota requirements are optimized. Soil replenishment with organic matter is the basis for fertility reproduction and rational use of mineral fertilizers. The importance of organic fertilizers, including those based on poultry manure, for soil fertility is beyond doubt [12-14]. There are also, although few, confirmations of the positive effect of such fertilizers on soybean productivity $[15,16]$. In addition, the rational use of straw-litter compost can be an economic alternative to the constantly rising cost of mineral fertilizers.

Many experiments have shown a positive effect of macro- and microfertilizers, and their combinations on the yield of seeds, their protein content, and the collection of protein and oil $[17,18]$. The pre-sowing application of ammonium nitrate is due to the value of the "starting" fertilizer for the development of soybean plants and the start of nitrogen fixation, established in some studies [19, 20].

The characteristic features of organic, mineral and trace element fertilizers could successfully complement each other, optimizing the production process. Nevertheless, we have not established any experiments on the comparative study of such types of fertilizers and their various combinations for soy.

The purpose of the research is to study the dynamics of organic matter and nutrients in typical chernozem, depending on fertilization level of soybean varieties.

\section{Materials and methods}

The research area is located in the southern forest-steppe of the Central Chernozem region, characterized by a moderate continental climate with an average annual temperature of $6.2^{\circ} \mathrm{C}$, the sum of average daily temperatures above $10^{\circ} \mathrm{C}$ about $2900^{\circ} \mathrm{C}$, and an average annual precipitation of $475 \mathrm{~mm}$. The annual hydrothermal coefficient is about 1 and indicates that the area is of unstable moisture. The probability of wet years is $25-40 \%$, semi-arid and arid $30-50 \%$.

Field studies were conducted on the basis of the UNITS "Agrotechnopark" of the Belgorod SAU n.a. V.Ya. Gorin in 2014-2016 in the grain crop rotation: soybean - winter wheat - buckwheat - millet. The soil of the experimental site is a typical heavy-loamy chernozem. Humus content $-5.1 \%$; pHsol. $=6.0$; content of mobile phosphorus and potassium (according to Chirikov) - 125-167 and 128-133 mg/kg of soil respectively.

Two-factor experience according to the $2 \times 8$ scheme. Factor A (variety): Lantsetnaya (early-ripening) and Belgorodskaya 48 (mid-ripening). The originator of soybean varieties is the Belgorod SAU. Factor B (fertilizer): 1. Control - without the use of fertilizers; 2. Strawlitter compost (hereinafter referred to as compost); 3. Compost + Ammonium nitrate (Naa); 4. Compost $+\mathrm{Naa}+$ Azosol; 5. Compost + Azosol; 6. Naa + Azosol; 7. Azosol; 8. Naa. Compost (20 t/ha) was applied in autumn under the main tillage with a BDT-5.4 disc harrow to a depth of 10-12 cm. Ammonium nitrate at a dose of $30 \mathrm{~kg} \mathrm{r}$.a./ha was introduced in the spring for pre-sowing cultivation. Treatment with microfertilizer Azosol 36 Extra at a dose of 21 /ha was carried out 2 times during the growing season in the phases of third triple leaf and budding. The total area of the plots was $37 \mathrm{~m} 2$, the accounting area was $25 \mathrm{~m} 2$, the 
repetition was three-fold, the placement of the plots was systematic by organized repetition method. Crop care included: first chemical treatment in the phase of first ternate leaf formation with preparations: Quickstep 0.8 1/ha + Harmony $6 \mathrm{~g} / \mathrm{ha}+$ Trend $90+$ Vantex 60 $\mathrm{ml} / \mathrm{ha}$; second chemical treatment was carried out in the phase of 3-4 ternate leaf with Fusilat Forte 1 1/ha.

Taking into account the terms of studied fertilizers application: autumn (straw-litter compost), spring (ammonium nitrate) and summer (Azosol 36 Extra), when it is impossible to determine the influence of some of them during the sowing period, it was decided to evaluate the effect and mutual influence of organic and mineral fertilizers on soil fertility by the dynamics of its indicators from the moment of compost application to soybean harvesting. Nutritional characteristics of the soil were determined by the following methods: organic matter - according to Tyurin; easy hydrolysable nitrogen - according to Kornfild; phosphorus - according to Chirikov; potassium - according to Chirikov.

The critical period of active growth of leaf-stem mass and the beginning of flowering for soybeans is at the end of June and the beginning of July in the Belgorod region. In 2014 and 2015 , the hydrothermal conditions of this time of the year were more favorable for the crop - in conditions of comfortable air temperature for soybean plants, the amount of precipitation was at or slightly higher than the long-term norm. In 2016, during this period, hot weather was observed with a significant lack of moisture, which affected the yield level.

Statistical processing of the research results was carried out by the method of variance analysis using the Microsoft Office Excel application software package.

\section{Results and discussion}

Due to the inertia inherent in soil organic matter, the most informative result of its dynamics is possible after a long period, a multiple to crop rotation. Nevertheless, there are crops of a multidirectional influence on the reproduction level of this indicator in the crop rotation. The value of agricultural crops increases with an increase in their soil-restoring ability, which also depends on the choice of agricultural techniques.

Given the importance of organic matter for soil fertility, it is extremely important to assess the dynamics of its content in the application of organic and mineral fertilizers and their joint use for soybean.

The results of three-year studies indicate that a negative balance of organic matter was observed in the control version without fertilizers $(-0.94 \%)$ and when using only foliar top dressing with Azosol (-0.22\%) (Table 1). This is quite understandable, since in both the first and second cases, fertilizers were not introduced into the soil, and the potential fertility of typical chernozem was used to form the crop, which led to the mineralization of organic matter.

When applying fertilizers to the soil, a positive balance was observed, the value of which varied significantly according to experiment variants. The largest increase in organic matter was in the variants of joint use of compost and ammonium nitrate $-0.52-0.68 \%$.

Azosol led to a slight decrease in the indicator, obviously due to the higher yield of soybeans when using a three-component fertilizer. Azosol had the same effect when it was used together in two-component variants with compost and ammonium nitrate. In comparison with the separate use of compost, the balance value decreased by $0.04 \%$, and the value of ammonium nitrate - by $0.1 \%$.

It can be assumed that the microelement fertilizer contributed to the additional mobilization of nutrients from soil organic matter. This could be a consequence of both the increased soybean yield and the increased activity of the symbiotic apparatus, which was noted in the Azosol application variants $[11,21]$. 
Varietal specificity in relation to the balance of soil organic matter was manifested in the fact that its positive value in the cultivation of mid-ripening variety Belgorodskaya 48 was preserved only in the variants of compost application, and its joint use with ammonium nitrate in two- and three-component fertilizer - $0.25-0.82 \%$. As already noted, Azosol reduces compost efficiency, in this case - to a negative balance $(-0.12 \%)$. The negative balance was also observed during the application of mineral fertilizers. Obviously, the growth of root system and microbiological pool does not compensate for lack of organic fertilizers.

Table 1. Dynamics of the content of organic matter and easily hydrolyzed nitrogen in the soil, depending on the level of fertilization of soybean varieties

\begin{tabular}{|c|c|c|c|c|c|c|c|c|c|}
\hline \multirow{3}{*}{$\begin{array}{l}\text { Fertilizer } \\
\text { (factor B) }\end{array}$} & \multicolumn{6}{|c|}{ Variety (factor A) } & \multicolumn{3}{|c|}{ Average for factor B } \\
\hline & \multicolumn{3}{|c|}{ Lantsetnaya } & \multicolumn{3}{|c|}{ Belgorodskaya 48} & \multirow[b]{2}{*}{1} & \multirow[b]{2}{*}{2} & \multirow[b]{2}{*}{ balance } \\
\hline & 1 & 2 & balance & 1 & 2 & balance & & & \\
\hline \multicolumn{10}{|c|}{ organic matter content, $\%$} \\
\hline Control no/f & 5.31 & 4.23 & -1.08 & 5.51 & 4.70 & -0.80 & 5.41 & 4.47 & -0.94 \\
\hline Compost & 5.38 & 5.68 & 0.30 & 5.53 & 5.79 & 0.25 & 5.45 & 5.73 & 0.28 \\
\hline Compost + Naa & 5.31 & 5.84 & 0.53 & 5.43 & 6.25 & 0.82 & 5.37 & 6.05 & 0.68 \\
\hline $\begin{array}{l}\text { Compost + Naa } \\
+ \text { Azosol }\end{array}$ & 5.34 & 5.73 & 0.39 & 5.37 & 6.01 & 0.65 & 5.35 & 5.87 & 0.52 \\
\hline $\begin{array}{l}\text { Compost }+ \\
\text { Azosol }\end{array}$ & 5.35 & 5.96 & 0.60 & 5.42 & 5.30 & -0.12 & 5.39 & 5.63 & 0.24 \\
\hline $\mathrm{Naa}+$ Azosol & 5.07 & 5.53 & 0.46 & 5.56 & 5.25 & -0.31 & 5.31 & 5.39 & 0.07 \\
\hline $\mathrm{Naa}$ & 5.17 & 5.67 & 0.50 & 5.61 & 5.43 & -0.17 & 5.39 & 5.55 & 0.17 \\
\hline Azosol & 5.33 & 5.16 & -0.17 & 5.26 & 4.99 & -0.27 & 5.30 & 5.08 & -0.22 \\
\hline $\begin{array}{l}\text { Average for } \\
\text { factor A }\end{array}$ & 5.28 & 5.48 & - & 5.46 & 5.47 & - & - & - & - \\
\hline $\begin{array}{l}\mathrm{LSD}_{05} \mathrm{~A} \\
\mathrm{LSD}_{05} \mathrm{~B} \\
\end{array}$ & $\mathrm{~F}_{\mathrm{f} .}<\mathrm{F}_{\mathrm{t}}$ & $\mathrm{F}_{\mathrm{f} .}<\mathrm{F}_{\mathrm{t}}$ & - & - & - & - & $\mathrm{F}_{\mathrm{f} .}<\mathrm{F}_{\mathrm{t} .}$ & 0.71 & - \\
\hline \multicolumn{10}{|c|}{ content of easily hydrolyzable nitrogen, $\mathrm{mg} / \mathrm{kg}$} \\
\hline Control no/f & 146.2 & 142.0 & -4.3 & 154.2 & 146.9 & -7.3 & 150.2 & 144.4 & -5.8 \\
\hline Compost & 154.2 & 145.8 & -8.4 & 152.7 & 147.4 & -5.3 & 153.5 & 146.6 & -6.8 \\
\hline Compost $+\mathrm{Naa}$ & 148.9 & 155.0 & 6.1 & 162.2 & 162.7 & 0.6 & 155.5 & 158.9 & 3.3 \\
\hline $\begin{array}{l}\text { Compost + Naa } \\
+ \text { Azosol }\end{array}$ & 150.2 & 159.4 & 9.2 & 156.6 & 163.8 & 7.2 & 153.4 & 161.6 & 8.2 \\
\hline $\begin{array}{l}\text { Compost }+ \\
\text { Azosol }\end{array}$ & 158.8 & 143.5 & -15.4 & 145.5 & 159.6 & 14.1 & 152.1 & 151.5 & -0.6 \\
\hline $\mathrm{Naa}+$ Azosol & 146.2 & 144.1 & -2.2 & 148.3 & 157.4 & 9.1 & 147.2 & 150.7 & 3.5 \\
\hline $\mathrm{Naa}$ & 148.7 & 141.3 & -7.4 & 153.4 & 147.0 & -6.4 & 151.0 & 144.1 & -6.9 \\
\hline Azosol & 145.7 & 138.0 & -7.7 & 140.3 & 138.3 & -2.0 & 143.0 & 138.2 & -4.9 \\
\hline $\begin{array}{l}\text { Average for } \\
\text { factor A }\end{array}$ & 149.9 & 146.1 & - & 151.6 & 152.9 & - & - & - & - \\
\hline $\begin{array}{l}\operatorname{LSD}_{05} \mathrm{~A} \\
\mathrm{LSD}_{05} \mathrm{~B} \\
\end{array}$ & $\mathrm{~F}_{\mathrm{f} .}<\mathrm{F}_{\mathrm{t} .}$ & 6.26 & - & - & - & - & $\mathrm{F}_{\mathrm{f} .}<\mathrm{F}_{\mathrm{t} .}$ & 12.52 & - \\
\hline
\end{tabular}

Note: 1 - before compost introduction (organic matter content) or before sowing (light hydrolyzable nitrogen content), 2 - during harvesting

The early-ripening variety Lantsetnaya helps to maintain a positive balance of organic matter in all variants of fertilization in the soil. It can be assumed that crop formation of the variety with a shorter growing season is largely due to the mineral nitrogen fertilizers and soil. This is confirmed by the negative balance in the content of easily hydrolyzable nitrogen in the soil under the early-ripening variety, except for two options for the joint use of compost and ammonium nitrate. These fertilizer options contribute to the transfer to another class of soil security - from low to medium - and the preservation of this status until the end of the growing season $155.0-159.4 \mathrm{mg} / \mathrm{kg}$ of soil. This is caused by maximum supply of nitrogen to the soil due to the application of these types of fertilizers.

Comparison of data on organic matter and nitrogen balance in the soil under the midripening variety Belgorodskaya 48, especially on the "compost + Azosol" and "ammonium 
nitrate + Azosol" variants, confirms the assumption that for the formation of phytomass and seed yield, this variety mainly uses nitrogen from the soil organic matter. When using these variants of fertilizers, the dynamics of this element is positive $-9.1-14.1 \mathrm{mg} / \mathrm{kg}$ of soil, and organic matter - negative.

In general, it can be assumed that when forming the soybean crop, the use of organic and mineral fertilizers separately did not compensate for the crop's need for nitrogen. In these variants, as well as in the control, the negative dynamics of the easily hydrolyzed nitrogen content was observed- -4,9-6,9 $\mathrm{mg} / \mathrm{kg}$ of soil. The joint application of compost and ammonium nitrate to the soil, as well as the joint use of mineral fertilizers, contributed to maintaining a positive balance of the element in the soil, the value of which in twocomponent fertilizers with ammonium nitrate was $3.3-3.5 \mathrm{mg} / \mathrm{kg}$, with the use of all types of fertilizers $-8.2 \mathrm{mg} / \mathrm{kg}$. At the same time, the highest soybean yield was formed $-3.0 \mathrm{t} / \mathrm{ha}$ (Table 2).

Table 2. Indicators of soybean varieties productivity depending on fertilization level

\begin{tabular}{|c|c|c|c|c|c|c|}
\hline \multirow[b]{3}{*}{ Fertilizer (factor B) } & \multicolumn{6}{|c|}{ Variety (factor A) } \\
\hline & \multicolumn{3}{|c|}{ Lantsetnaya } & \multicolumn{3}{|c|}{ Belgorodskaya 48} \\
\hline & $\begin{array}{l}\stackrel{J}{S} \\
\frac{\tilde{D}}{\tilde{D}} \\
\frac{\pi}{\lambda}\end{array}$ & 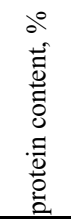 & 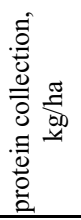 & $\begin{array}{l}\frac{\pi}{S} \\
\frac{\vec{d}}{d} \\
\frac{D}{\delta}\end{array}$ & 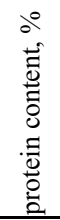 & 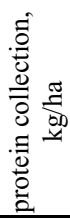 \\
\hline Control no/f & 2.46 & 35.3 & 868 & 2.58 & 33.7 & 869 \\
\hline Compost & 2.88 & 37.6 & 1083 & 2.86 & 36.9 & 1055 \\
\hline Compost $+\mathrm{Naa}$ & 2.81 & 39.1 & 1099 & 2.93 & 38.8 & 1137 \\
\hline $\begin{array}{l}\text { Compost + Naa }+ \\
\text { Azosol }\end{array}$ & 3.01 & 39.2 & 1180 & 3.04 & 39.0 & 1186 \\
\hline Compost + Azosol & 2.79 & 37.6 & 1049 & 3.01 & 36.8 & 1108 \\
\hline $\mathrm{Naa}+\mathrm{Azosol}$ & 2.84 & 36.0 & 1022 & 2.90 & 34.6 & 1003 \\
\hline $\mathrm{Naa}$ & 2.79 & 36.7 & 1024 & 2.86 & 36.1 & 1032 \\
\hline Azosol & 2.71 & 38.1 & 1033 & 2.81 & 36.3 & 1020 \\
\hline Average for factor $\mathrm{A}$ & 2.79 & 37.5 & 1045 & 2.88 & 36.5 & 1051 \\
\hline $\begin{array}{l}\mathrm{LSD}_{05} \mathrm{~A} \\
\mathrm{LSD}_{05} \mathrm{~B} \\
\end{array}$ & $\begin{array}{l}0.16 \\
0.33\end{array}$ & $\begin{array}{l}1.21 \\
2.42 \\
\end{array}$ & - & - & - & - \\
\hline
\end{tabular}

The positive dynamics of easily hydrolyzed nitrogen content in the soil may indicate a sufficient supply (no shortage) of soybean plants with this nutrient, which determines the protein accumulation in seeds. Indirect confirmation of this is the highest protein content in seeds of both early- and mid-ripening varieties in the variants of compost and ammonium nitrate use $-38.8-39.2 \%$. Obviously, it was the organic component of the fertilizer that provided the most optimal mode of protein production and storage, since with the joint use of ammonium nitrate and Azosol, despite the positive dynamics of easily hydrolyzed nitrogen content, the protein content in the seeds of both varieties was minimal, surpassing only the control variant - 34.6-36.0\%.

The optimal nitrogen supply of soybean plants depends not only on the amount of its forms available to plants in the soil, but also on the balanced supply of mobile phosphorus and exchangeable potassium.

The importance of phosphorus in plant life is difficult to overestimate. It is an essential element that plays an important role in metabolic processes, photosynthesis, respiration, and promotes symbiotic nitrogen fixation. As a result, many studies have established a high responsiveness of soybeans to phosphorus fertilizers [16, 22]. 
Analysis of the mobile phosphorus content in typical chernozem for soybean cultivation showed that the soil of the experimental site belongs to the class of high element content from 111.2 to $132.5 \mathrm{mg} / \mathrm{kg}$ (before composting).

When compost was applied separately or together with mineral fertilizers for crop harvesting, the content of mobile phosphorus in the soil increased and it was transferred by grouping to a higher gradation - to a high security class $(163-196 \mathrm{mg} / \mathrm{kg})$. Except for the "compost + Azosol" variant under the early-ripening variety Lantsetnaya.

It should be noted that the dynamics of mobile phosphorus content in the soil under the crops of the studied varieties mainly had similar features and did not depend on the varietal affiliation. The negative balance was noted in the control variant without fertilizers and with the use of mineral fertilizers, which is fair enough, since phosphorus was not introduced into the soil in these variants, and the growth and development of plants occurred due to the potential fertility of typical chernozem. As a result, when using ammonium nitrate separately and together with Azosol for harvesting, according to mobile phosphorus availability (77-87 $\mathrm{mg} / \mathrm{kg}$ ), the soil belonged to a lower class - medium, as well as in the case of foliar top dressing on a mid-ripening variety $(100 \mathrm{mg} / \mathrm{kg})$.

Thus, the dynamics of mobile phosphorus content in the soil was mainly influenced by fertilizers. The element increase in the soil is associated with the introduction of compost and ranged from 36 to $47 \mathrm{mg} / \mathrm{kg}$, apparently completely providing the bioproduction process with this nutrient (Fig. 1).

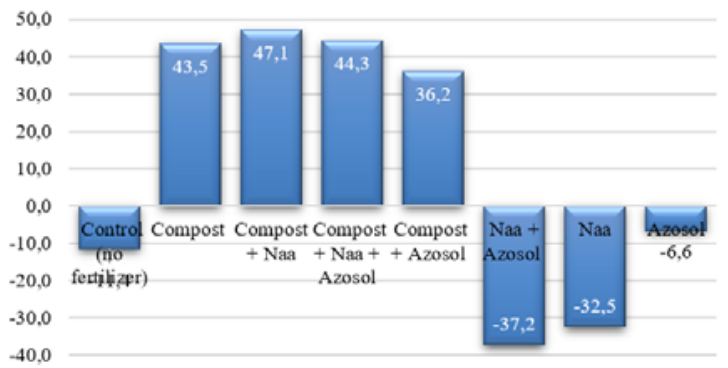

Fig. 1. Balance of mobile phosphorus content in the soil, $\mathrm{mg} / \mathrm{kg}$

The negative balance value of mobile phosphorus content in typical chernozem when using mineral fertilizers (from -7 to $-32 \mathrm{mg} / \mathrm{kg}$ ) is probably due to the level of nitrogen nutrition and, ultimately, the crop productivity.

Potassium is just as necessary for plants as nitrogen and phosphorus. Potassium is involved in photosynthesis and transfer of its products, regulation of water regime of plants, contributes to the increase of plant resistance to adverse factors and symbiotic activity, yield of soybean seeds and their protein content.

Analysis of the dynamics of exchangeable potassium content in the soil indicated its fundamental similarity with the balance of mobile phosphorus, obviously due to the conjugation of their consumption by soybean plants depending on the applied fertilizers. A positive balance of exchangeable potassium content was also observed in all variants with the introduction of straw-litter compost: from $5.4 \mathrm{mg} / \mathrm{kg}$ in case of single-component fertilizer to $21-43 \mathrm{mg} / \mathrm{kg}$ - when compost was used together with mineral fertilizers (Fig. 2). Without additional application of potassium-containing fertilizers, the dynamics of exchangeable potassium content in the soil was negative from -7 to $-22 \mathrm{mg} / \mathrm{kg}$, except for the use of Azosol on the early-ripening variety Lantsetnaya $(6.2 \mathrm{mg} / \mathrm{kg})$. Apart from the quantitative values, this is the only difference between the varieties for this indicator. 


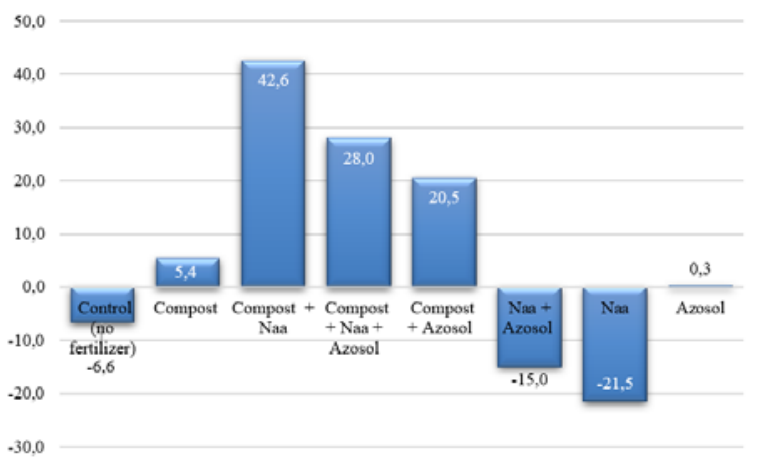

Fig. 2. Balance of exchangeable potassium content in the soil, $\mathrm{mg} / \mathrm{kg}$

Before fertilization, the soil of the site was characterized by a borderline state in terms of the availability of exchangeable potassium between increased and high: the element content varied from 112 to $125 \mathrm{mg} / \mathrm{kg}$. In the variants with the compost introduction, the content of exchangeable potassium increased to $125-168 \mathrm{mg} / \mathrm{kg}$ and belonged to the high provision class.

\section{Conclusion}

As a result of three-year studies, it was found that without fertilizers introduction to the soil, a negative balance of organic matter was observed in the control variant and when applying foliar top dressing $--0.94 \%$ and $-0.22 \%$, respectively. The largest increase in organic matter in the soil was in the variants of joint use of compost and ammonium nitrate $-0.52-0.68 \%$. The combination of compost and ammonium nitrate, as well as the joint use of mineral fertilizers, contributed to maintaining the positive balance of easily hydrolyzed nitrogen in the soil from 3.3 to $8.2 \mathrm{mg} / \mathrm{kg}$.

Analysis of the dynamics of organic matter and nitrogen suggested that the early-ripening soybean variety Lantsetnaya mainly used nitrogen of mineral fertilizers for crop formation, while the mid-ripening variety Belgorodskaya 48 is more responsive to the use of compost.

The introduction of compost also caused an increase in mobile phosphorus content in the soil by $36-47 \mathrm{mg} / \mathrm{kg}$ and the exchangeable potassium by $5.4-43 \mathrm{mg} / \mathrm{kg}$. This contributed to the transfer by grouping to a higher gradation - to a high class of supply in terms of the content of both mobile phosphorus (163-196 mg/kg) and exchangeable potassium (125-168 $\mathrm{mg} / \mathrm{kg}$ ).

The increase in fertilization level of soybean crops based on the use of straw-litter compost contributed to the positive dynamics of organic matter and nutrients (NPK) in typical chernozem, the formation of higher yields, protein content and collection.

\section{References}

1. O.G. Shabaldas et al, The Agrarian Scientific Journal, 8, 48 (2020)

2. Z. Shea, W.M. Singer, B.Zhang, Soybean Production, Versatility, and Improvement In book: Legume Crops, 1 (2020)

3. World Oilseed Production, https://www.statista.com

4. C. Hickmann et al, Rev. Agrogeoambiental, 9(2), 37 (2017)

5. A.P. Gaspar et al., Crop Sci., 57, 2193 (2017)

6. Kh.A. Khamokov, Vtstnik of the Altai State Agrarian University, 1(159), 30 (2018) 
7. M.L. Taov, Bulletin of VIUA, 115, 162 (2001)

8. Marketing research: Soybean market for 2015-2019, OGAU "Innovation and Consulting Center of the Agro-industrial complex", 19 (2020)

9. A.V. Turyansky et al., Eco. Env. \& Cons., 24(3), 1048 (2018)

10. E.S. Savchenko, Agro-industrial complex: Economy, Management, 1, 4 (2018)

11. E.G. Kotlyarova et al, Int. J. Adv. Biotechnol. Res., 8(4), 1156 (2017)

12. S.D. Litsukov et al, Bioscience Biotechnology Research Communications, 12(5), 152 (2019)

13. R.T.X. Sousa et al, JCEC, 6(04), 0513 (2020)

14. A. Shakya, T. Agarwal, Int. J. Curr. Microbiol. App. Sci., 6(10), 2657 (2017)

15. S. Pokhrel, Agronomy, 11, 119 (2021)

16. Kh.A. Shaban et al., ASRJ, 4(3), 44 (2020)

17. M. Jangilwad et al., Int. J. Curr. Microbiol. App. Sci, 8(11), 2113 (2019)

18. T. Kinugasa et al, J Plant Res, 125, 275 (2012)

19. R. Juraeva et al, Plant Cell Biotechnology and Molecular Biology, 21(61-62), 72 (2020)

20. A. Gadimov, Bulletin MRSU, 4, 44 (2010)

21. V.G. Gritsina, E.G. Kotlyarova, Innovations in Agricultural Complex: Problems and Perspectives, 4(16), 52 (2017)

22. J. Bairwa et al., Int. J. Curr. Microbiol. App. Sci, 9(9), 527 (2020) 